\title{
Structural System to Resist Seismic Loads on High Rise Reinforced Concrete Structures
}

\author{
Ramy Morsy Elkholy \\ Faculty of Engineering, El-Mansoura University, Mansoura, Egypt \\ Email:engr.ramyelkholy@gmail.com
}

How to cite this paper: Elkholy, R.M. (2017) Structural System to Resist Seismic Loads on High Rise Reinforced Concrete Structures. Open Journal of Civil Engineering, 7, 297-302.

https://doi.org/10.4236/ojce.2017.72019

Received: April 19, 2017

Accepted: June 23, 2017

Published: June 26, 2017

Copyright $\odot 2017$ by author and Scientific Research Publishing Inc. This work is licensed under the Creative Commons Attribution International License (CC BY 4.0).

http://creativecommons.org/licenses/by/4.0/

\begin{abstract}
The forces of nature represent the biggest challenge for engineering work in general and perhaps the most prominent of these forces. This generated by earthquake where engineering structure is exposed abnormal loads and stresses which places areal burden on structural engineers to find solutions and structural systems to increase resistance and effectiveness of engineering structure especially high rise concrete structures.
\end{abstract}

\section{Keywords}

Lateral Loads, Seismic Loads, Earthquake Loads, Axial Force

\section{Introduction}

Increasing the height of the building increases the effect of lateral loads on the building.

The column-beam joints and the contact joint between column and the column in next floor are the prominent joints exposed to seismic loads in structure.

Strong column-weak beam joint is important concept in resisting seismic loads.

This study is devoted to increase resist of structure by increase effectiveness and resistance of the contact joint between column and the column in next floor (column-column joint).

It is common in construction sites the pouring of concrete columns for each floor separately, the cohesion between columns one top of each for multiple stories structure by extension of steel bars mostly does not exceed 1.0 meter, so full height column of structure can be represented as a group of units of columns pouring one top of each, this may not represent a problem for low-rise structures but for sure represent a problem for high-rise structures especially when structure exposed to seismic loads as shown in (Figure 1 and Figure 2). 


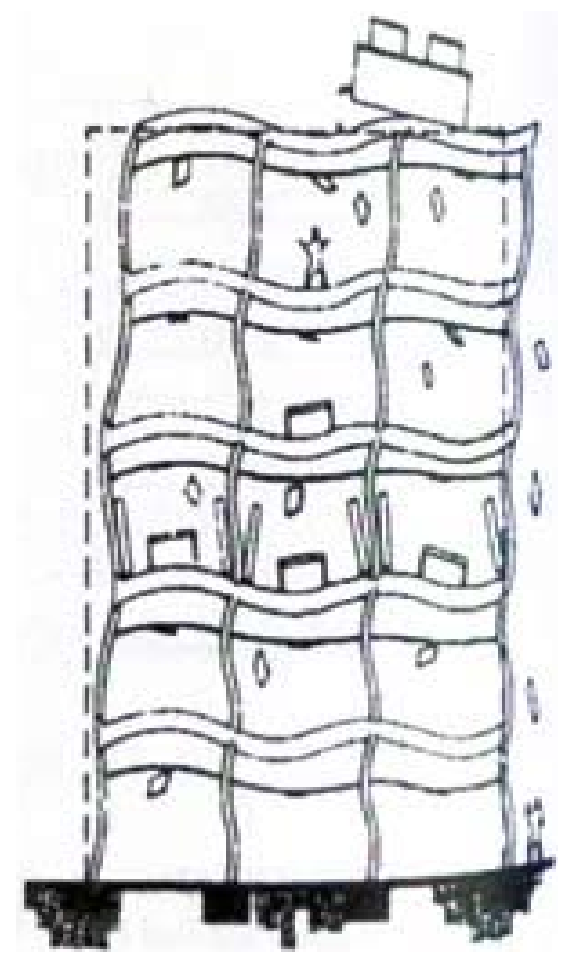

Figure 1. Behavior of building under seismic loads [2].
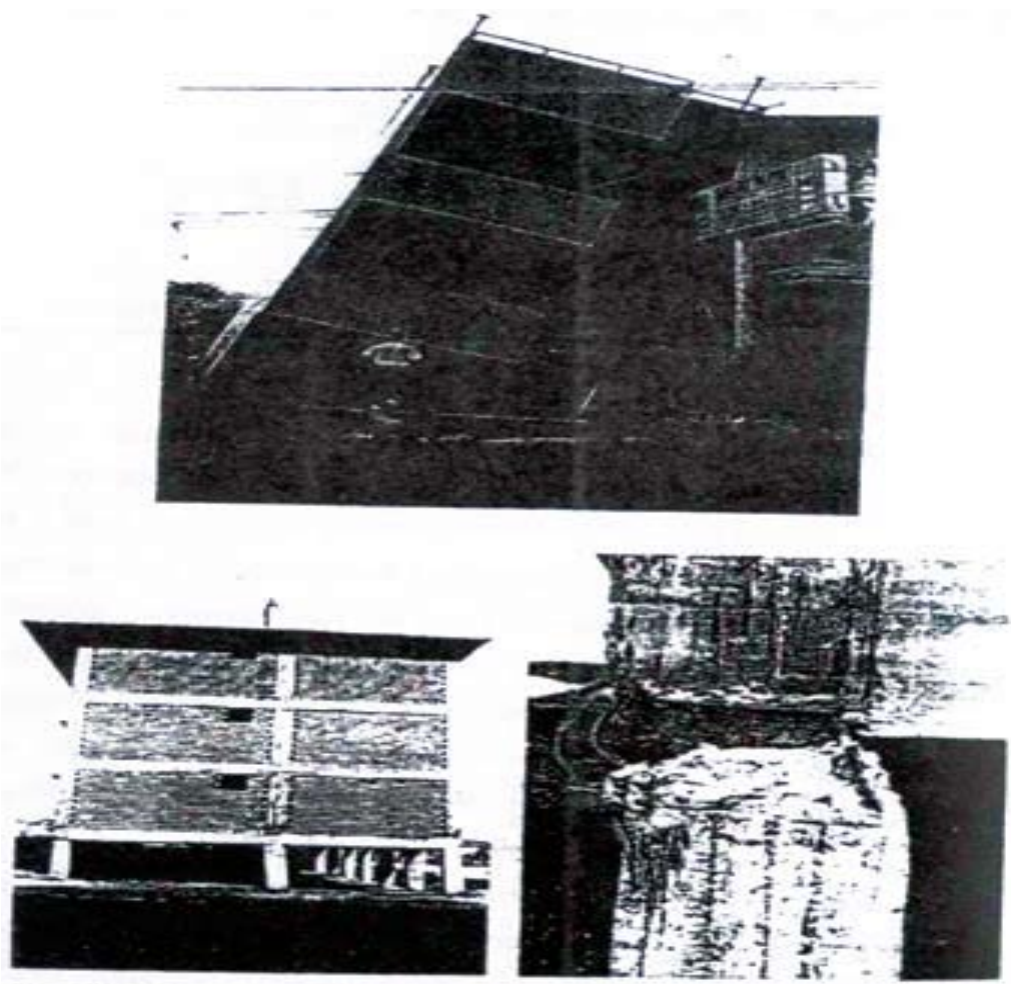

Figure 2. photographs of damage caused by earthquakes [2].

\section{Search Theory}

The purpose of study to make each vertical group of columns to behave as one unit as if columns have poured once building length. 


\section{Practical Application}

As shown in (Figure 3) in-site are pouring columns under axial force by hydraulic jacks (Figure 4) that will retain until concrete hardening by using hydraulic jacks then will pouring next floor columns under the same axial load that will retain until concrete hardening and repeat the same steps for each floor columns.

The cables used should be continuous full length of columns by using rolls of cables and installed in foundation steel bars.
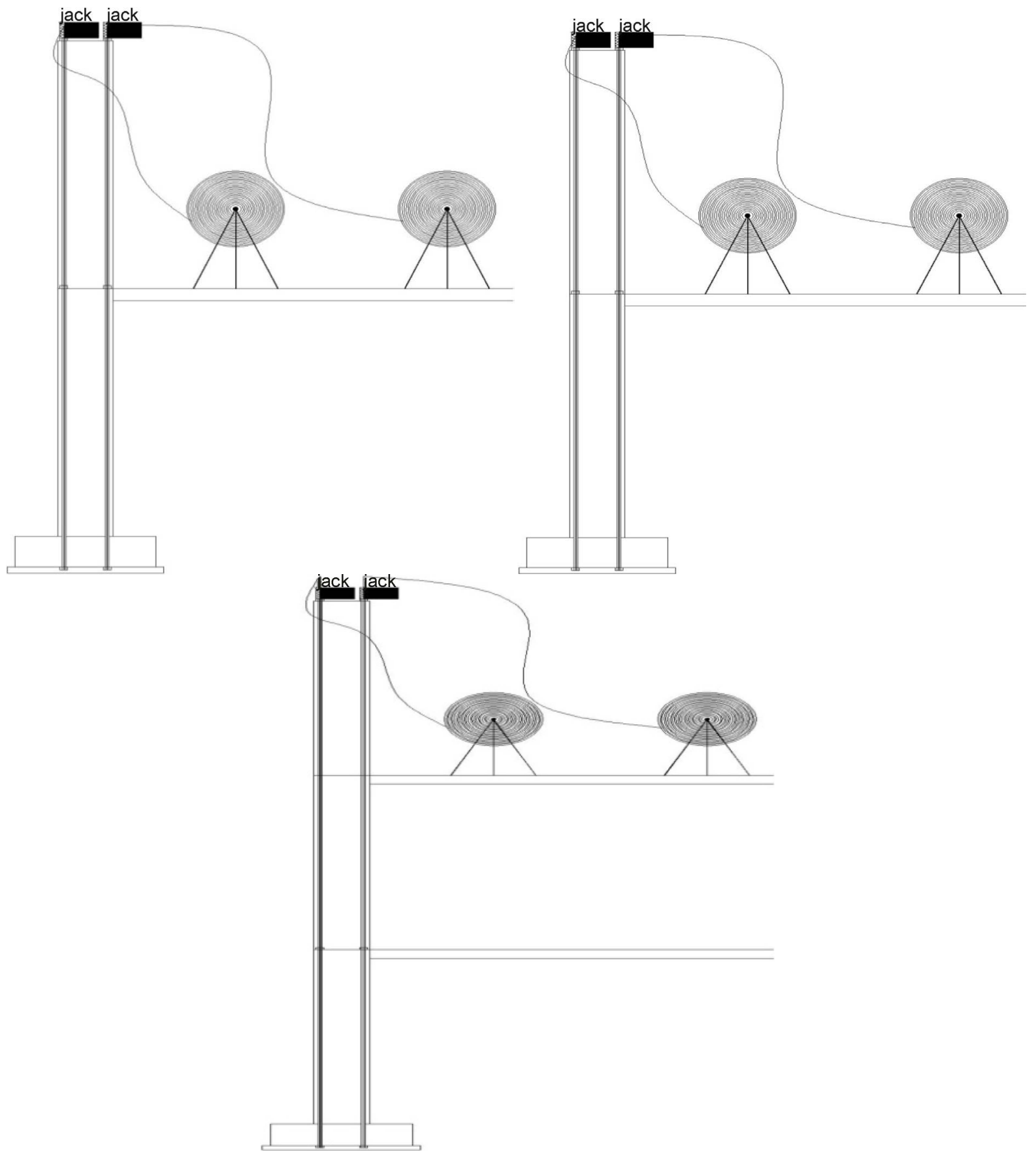

Figure 3. Steps of implementation in the site. 
The cables rolls should be moved from floor for the floor who followed with continuity of cables.

Finally structure columns will be subjected to the same axial load full height of the building and every vertical row of columns will behave as one column.

\section{Mathematical Achievement}

It is now generally recognized that beam-column joints can be critical regions in reinforced concrete frames can be critical regions in reinforced concrete frames designed for in elastic response to seismic attack.

As a consequence of seismic moments in columns of opposite signs immediately above and below the joint, and similar beam moment reversal across the joint.

The Joint region is subjected to horizontal and vertical shear forces [2].

It is assumed that due to gravity loads and earthquake-induced lateral forces on the frame, typical moments, shear and axial forces introduced to an interior joint are shown in Figure 5 \& Figure 6. To enable simple equilibrium requirements, compression stress in the concrete and steel by symbols $\left(C_{c}\right),\left(C_{s}\right)$ respectively, horizontal joint shear force and vertical joint shear force are denoted
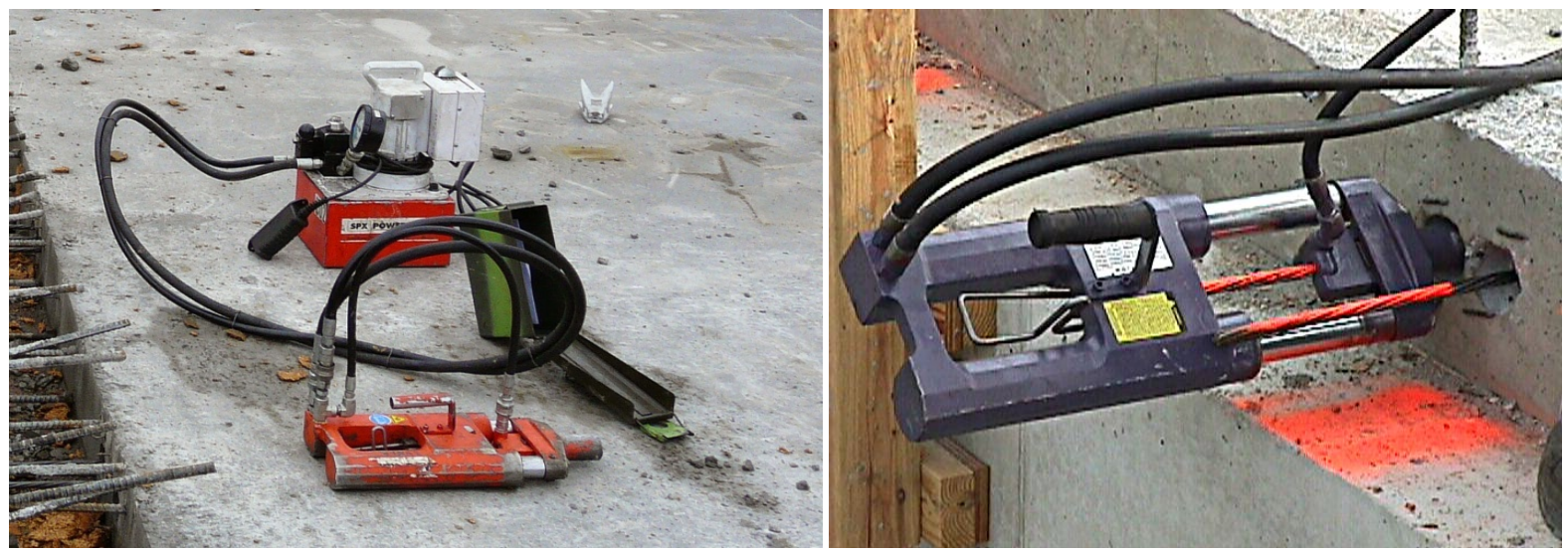

Figure 4. Shapes of hydraulic jacks [2].

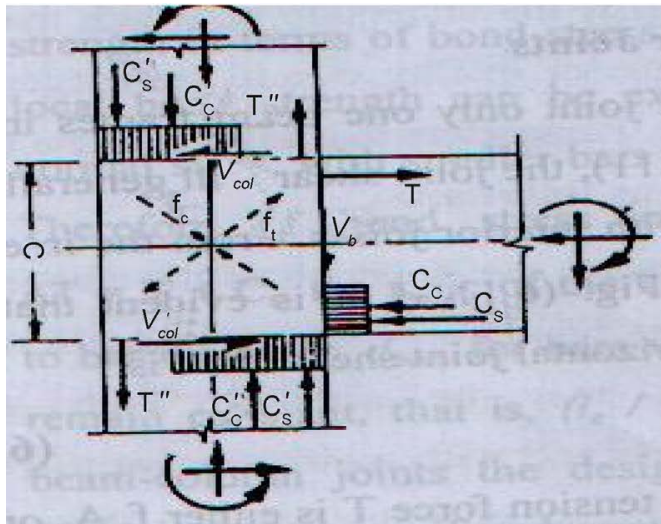

(a)

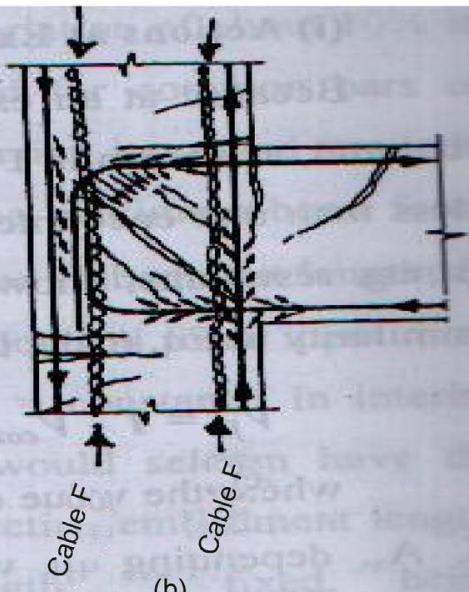

(b)

Figure 5. External actions and internal stress resultants at (beam—column joint) [2]. 
by $\left(V_{j h}, V_{j v}\right)$ respectively [2].

$$
\begin{gathered}
V_{j h}=T+C_{c}^{\prime}+C_{s}^{\prime}-V_{c o l}=T+C_{c}+C_{s}-V_{c o l} \\
\left(T^{\prime}=C_{c}^{\prime}+C_{s}^{\prime}\right) \\
V_{j h}=T+T^{\prime}-V_{c o l} \\
V_{j v}=T^{\prime \prime}+T^{\prime \prime \prime}-P_{u} / 2-V_{b}-F_{c} \quad\left(F_{c}=\text { Cable force }\right)
\end{gathered}
$$

When we use this new technique in pouring columns we will generated new force is called Cable force $\left(F_{c}\right)$ which is reduced shear forces on column-beam Joint and by controlling $\left(F_{c}\right)$ we can prevented a chance to joint shear failure.

\section{Indications}

$\mathrm{T}$ : tension stress in steel bars in upper half of interior joint

$T^{\prime}$ : tension stress in steel bars in lower half of interior joint

$T^{\prime \prime}$ : tension stress in steel bars in right half of interior joint

$T^{\prime \prime \prime}$ : tension stress in steel bars in left half of interior joint

Vcol.: the average of column shears above and below the joint

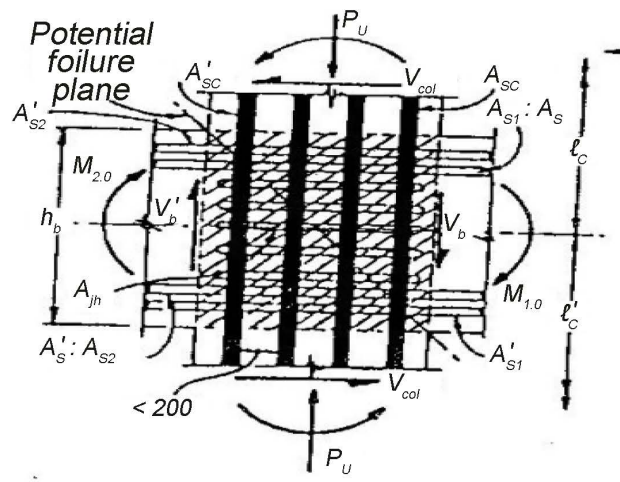

(a)

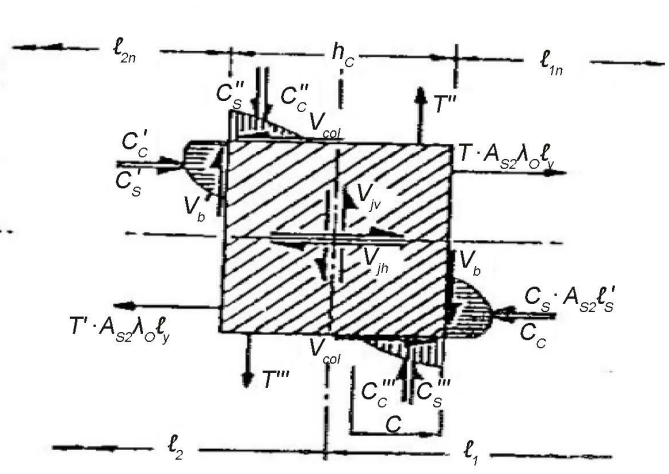

(b)

Figure 6. Analysis forces resultants at internal (beam-column joint) [2].

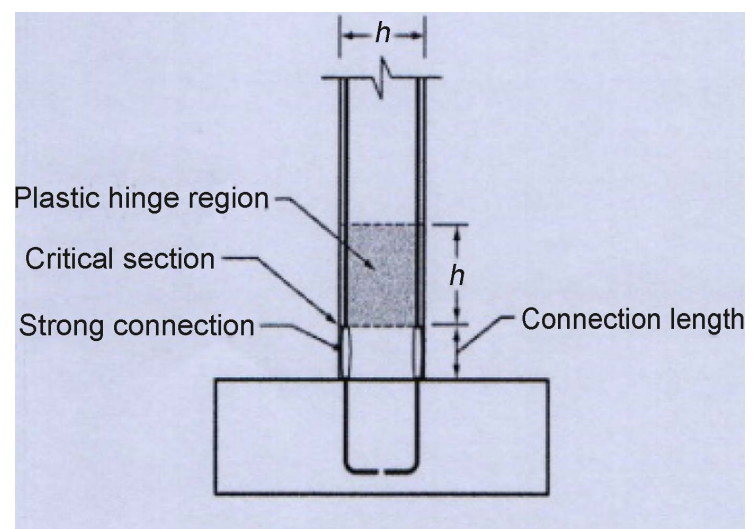

(d) Column-to-footing connection

Fig. R21.8.3—Strong connection examples.

Figure 7. One of critical section may be happened in column [1]. 

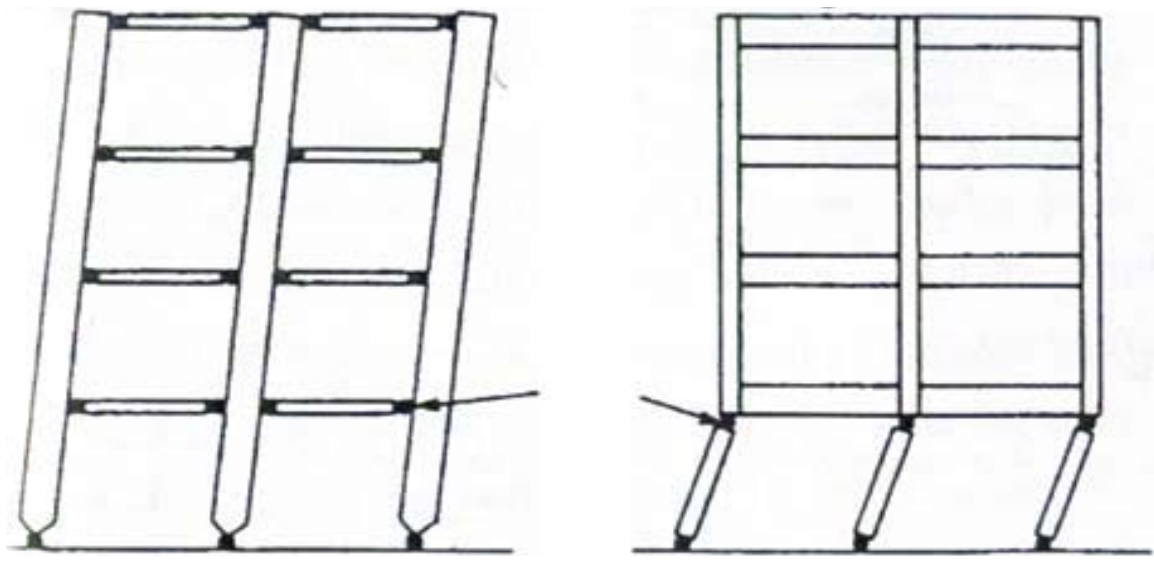

Figure 8. The effect of the system to increase resist of buildings to seismic loads [2].

\section{Conclusions}

The study will achieve important principle (strong column-column) joint and will give more support to critical section in columns (column-to-footing connection) (column-to-column connection) as shown in Figure 7 \& Figure 8.

Figure 8 shows the effect of the suggested system to resist seismic loads, in the structure on the left columns behaves as one unit.

Structure on the right where the normal method in building is used additional stresses which are generated in earthquakes.

\section{Finally}

The system can be used in high rise reinforced concrete buildings, cable suspended bridges with large spans.

\section{References}

[1] ACI Committee 318 (2008) Building Code Requirements for Reinforced Concrete (ACI 318-2008) and Commentary. American Concrete Institute, Farmington Hills, 348.

[2] Yousef, A. (2010) Lectures Notes on: Design of Reinforced Concrete StructuresPart 111. Fourth Year Civil, El-Mansoura, 175-189. 
Submit or recommend next manuscript to SCIRP and we will provide best service for you:

Accepting pre-submission inquiries through Email, Facebook, LinkedIn, Twitter, etc. A wide selection of journals (inclusive of 9 subjects, more than 200 journals)

Providing 24-hour high-quality service

User-friendly online submission system

Fair and swift peer-review system

Efficient typesetting and proofreading procedure

Display of the result of downloads and visits, as well as the number of cited articles Maximum dissemination of your research work

Submit your manuscript at: http://papersubmission.scirp.org/

Or contact ojce@scirp.org 